\title{
ENHANCING THE SPEAKING SKILL USING METACOGNITIVE STRATEGY (A CASE STUDY ON HIGH-ACHIEVER STUDENTS IN A PRIVATE UNIVERSITY IN NORTH MALUKU)
}

\author{
Ismit Hi. Karim \\ Sekolah Tinggi Ilmu Keguruan dan \\ Pendidikan (STKIP) \\ Ismetkarim89@gmail.com
}

\begin{abstract}
This paper reports a qualitative case study which aims to investigate the use of metacognitive strategly in developing the autonomous students' speaking skill which is based on the participants' metacognitive awareness and kind of metacognitive strategy use. Six autonomous learners are corisidered as highachiever students who took part as the participants through purposive sampling. The in-depth interview, based on the Strategy Inventory for Language Learning (SILL), was chosen in order to grasps the data regarding their speaking learning using metacognitive strategies, which then analyzed using a thematic analysis. The findings revealed that most of the High-Achiever students were having difficulties in their speaking learning as they just started to study proper English when they decided to attend the university. Thus, to allow them make the best use of their metacognitive strategy, they applied cognitive knowledge strategies and socio-affective strategies in dealing with their metacognitive processes such planning, monitoring, and evaluation in their speaking learning. Moreover, in developing their metacognitive awareness, the participants were found affected by two factors, self-appraisal and self-management.
\end{abstract}

\section{INTRODUCTION}

Communication competence, which coined by Dell Hymes in 1967, has been a major discuss by scholars for many decades resulted in various theories. However, generally speaking, it consists of multiple competencies. One of the competencies drawn by Celce-Murcia (1995) as competence which covers other communicative competencies in her model is Strategic Competence. Based on her statement, this competence is highly crucial in order to build a better oral communication skill. To support the idea, some scholars (Dornyei and Thurrell, 1991; Canale and Swain,1980) saw this competence as one's ability to overcome the problem due to the lack of knowledge regarding the language learning. More specific, Oxford (2001) noted that strategy in language learning consists of some specific behaviors such as cognitive strategy, metacognitive strategy, and memory-related strategy.

In line with the discussion above, numbers of scholars have defined the metacognition in learning. Tang (2016) sees metacognition as a person's self-awareness on their processes of cognitive in learning. The earlier scholar such as Livingston (1997) described metacognition as the high level of thinking involving the active supervision on one's cognitive processes. Psychologist John Flavell (1979, as in Livingston, 1997) even divided the metacognition into two parts; Metacognitive knowledge, which is according to Brown (1987), is the awareness of individual cognitive ability, and Metacognitive regulation, which refers to the one's way of administering the cognitive processes (Cambridge International Examination, 2015). Moreover, supporting the discussion, Celce-Murcia $(1995,2007)$ noted that metacognitive applies two other specific behaviors in its processes as it covers learners cognitive and memory approach of their learning experience which she called cognitive strategy and memory-related strategy.

O'Malley and Chamot (1990) stated that those who do not use metacognitive approaches in their learning are those who simply learn without planning, monitoring, and direction in their learning. This notion has stated the importance of metacognition in one's learning processes, especially in language learning. Others scholars (Wended, 1999; Tang, 2016; Xu, 2012; Anderson, 2002; Blakey \& Spence, 1990; Livingston, 2003; Chamot \& Robbins, 2007) also mentioned that the metacognition in second language learning is divided into planning for learning, selecting and monitoring the learning strategy, orchestrating various strategy use, and evaluating the learning. Those metacognition models will help a learner to be more apprehensive on what kind of strategy they use during their learning processes (Rahimi \& Katal, 2012, and 
Anderson, 2002). However, Raoofi et al (2014) reported their study on some factors which affected the individuals' metacognition in language learning. Those factors were identified as language proficiency, education level, bilingualism, learning styles, and first language metacognitive language use.

Based on the earlier theories which mentioned that planning, monitoring, and evaluating as part of the steps in applying metacognitive strategy, language learners who manage their learning themselves make them be autonomous learners. To support the statement, Stewner-Manzanares et al. (1985) made a persuasive account that there is a strong link between metacognitive strategy and becoming an independent ESL learner. Other scholars (Fahim \& Dorrimanesh, 2015; Cotteral, 1995) also asserted that a self-directed learner or so-called independent learner establish their autonomy in learning through making a right decision on the learning strategy which suits the tasks given. Stewner-Manzanares et al. (1985) provided a more specific description on metacognitive strategy by dividing it into specific strategies of self-regulatory namely self-management, functional planning, advance organization, selective attention, delayed production, selfmonitoring, and self-evaluation. Thus, the notions which described earlier shows that the metacognitive strategies will improve students' language learning outcomes specifically in Speaking skill.

Speaking skill, despite its popularity among English language learners and organization around the globe (Crystal, 1997), come up with its challenges as well. Torky (2006) draws his notion in speaking into three challenges, namely speaking is face to face, speaking as the interactive activity, and speaking happened in real-time. This challenge requires immediate feedback, using turn-taking during its practice, unprompted responses, and time pressures as it occurred in a real situation. While in the other hand, students who are lack of English, such as the participants in this research, would likely to confront with their problems asserted by Ur (1996) as inhibition, nothing to say, low and uneven participation, and mothertongue use. This issue is profoundly affected by their speaking skill. Thus, the metacognitive strategies, as discussed earlier, will take part to overcome the problem.

Based on the discussions above, this research was conducted on the purpose of investigating the independent language learners which in this case characterized as "High-Achiever Students" on how they implemented the metacognition into their learning to improve their speaking skill. Thus, the research has been conducted based on the following research questions:

1. How do high-achiever students enhance their awareness of using Metacognitive strategies?

2. What kind of learning strategies do the high-achiever students use in accommodating the metacognitive strategy in speaking learning?

\section{METHOD}

This research was conducted using the descriptive case study which purposed to investigate and described the metacognitive strategy used by high-achiever students in their learning of speaking. Biddix (2009) provide the characteristics of qualitative research such as commonly based on social constructivism, applies slightly few number of participants, applies observation, interviews, and content data, and interpretation is based on the researchers' point of view and the data available. In line with it, Cohen et al. (2005:1) asserted that a case study research "provides a unique example of real people in real situations, enabling reader to understand ideas more clearly than simply by presenting them with abstract theory or principles". Thus, to conclude it, Merriam (1988, in Hamilton and Corbett-Whittier, 2012) stated that the descriptive case study focuses on comprehensive descriptions of what being researched.

Using purposive sampling, the participants were "handpicked" by the researcher based on the needs of the study (Cohen et al., 2013; Crossman, 2012). Participants in this research were six students (two males and four females) of the English department in a private university in North Maluku, Indonesia, which characterized as high-achiever students. These students are limited only to those who have achieved a high score on their academic report on speaking skill. The reason of choosing these students is to get more abundant data of the interview as those students came from a remote area in Halmahera who have a limited time of being exposed to the English subject in school due to limited teachers and facility.

In the purpose of obtaining more data based on the research questions, the writer applied the in depth interview as according to Boyce and Neale (2006), it allows the researchers to carry an intensive interview on the research subject. This type of interview enables the researcher to dig more on the case, which is researched trough follow-up questions based on the responses given by the respondents. Furthermore, to gain the information on the metacognitive strategies used by the high-achiever students, the interview questions were developed using Strategy Inventory for Language Learning (SIIL) which developed by Rebecca Oxford (1986, in Oxford, 1995). The interview was conducted for 30 minutes to 1 hour each participant and being developed based on the theoretical basis in this research. The interviews were then recorded using a computer app called Audacity.

The recorded audio was transformed into the script data, coded with open coding, then analyzed using the thematic analysis. This kind of analysis technique enables the researcher to divide the participants' responses to specific themes based on the need of the researcher. Braun and Clarke (2014) noted that the thematic analysis serves the researcher to develop the complicated qualitative data analysis into a somewhat accessible data which can be useful for people in general to understand. The data then interpreted to gain information from the recording of the interview. 


\section{FINDINGS AND DISCUSSION}

As mentioned in the earlier paragraph, the analysis was carried out using thematic analysis based on the responses of the participant. Thus, in this paper, the researcher classified the findings and discussion into two categories based on the research questions proposed as follows:

\section{How the high-achiever students develop their awareness of using metacognitive strategy}

From the data of the interview, the writer found out that some factors affected their awareness of using the metacognitive strategy during their learning of speaking. Those factors are the participants' English language backgrounds, the difficulties they face during their learning, and their access to learning resources.

Seeing from their English language backgrounds, the researcher discovers that most of the participants (5 out of 6 ) were from rural areas of Halmahera island which mainly exposed to English subject when they attended the high school due to limited access on resources and facilities. A participant even admitted that he did not learn English with teachers due to the lack of English teachers in their village. Thus, most of the participants were admitted to have a bad attitude to English subject during their school time. The limitation of the information, teachers, and access to resources which has been an issue during their high school time, admitted by the participants as the main issue, lead them to the difficulties in learning speaking. Most of the participants admitted they lacked of vocabularies, grammar usage, pronunciation, and experienced psychological issues such as anxiety and nervousness.

Being in the new environment when they attended the university in the city of Ternate have led them to be more developed in term of their attitude towards English, more specifically, English speaking skill. Easy access to the speaking learning resources in the city encourage the participants to develop the strategy of learning using available learning platforms, enabling them to improve their knowledge of speaking based on the difficulties they encountered. These facts were determined by their self-appraisal which consist of their learning environments and cognitive knowledge (Paris \& Winograd, 1990).

In line with the paragraph above, the participants recorded the activities to develop their metacognitive strategy to make the best use of the learning communities both in the class and outside the class, and used them to assist their process of planning their learning, monitoring their performance, and evaluating their learning with pairs. Supporting their activity, Blakey and Spence (1990) asserted that metacognitive environment pushes a language learner to think about their learning activity such as preparing for their learning, deciding the suitable learning strategy related to their needs and evaluates their learning processes. Furthermore, using the environments to support their metacognitive learning, they admitted that the easy access to the learning sources such as books, and internet access also took a crucial role in their learning of speaking. Their cognitive knowledge supported these activities, as Brown (1987, in van Velzen, 2016) stated that one's' metacognitive knowledge is developed based on his/her cognitive processes. Moreover, the participants also revealed that they used their cognitive strategies such as note-taking, auditory representation, and cooperation to help them improve their metacognitive strategies. These activities then automatically develop their self-management during their focus on the target of mastering speaking skill Rivers (2001).

\section{The kind of learning strategies the high-achiever students use in accommodating the metacognitive strategy in speaking learning}

As described by scholars (O'Malley \& Chamot, 2007; Wended, 1999; Tang, 2016; Xu, 2012; Anderson, 2002; Blakey \& Spence, 1990; Livingston, 2003; Chamot \& Robbins, 2007), there are three steps to develop metacognitive strategy. They are Planning, Monitoring, and Evaluating the learning, and the researcher divided the participants following these steps:

\section{Planning}

From the findings, the participants revealed that they have to set a goal before planning their learning. This is crucial in planning the learning as learning strategy refers to the conscious activity towards the language learning goal (Oxford, 2003). The planning enables the language learners to prepare their learning for the goal of having a better result in their learning (McCormick, 1995 in Oxford, 2003). Thus, the participants mainly admitted that they were planning their goal of learning based on other students or seniors, which according to them, were successful in developing their speaking skill. The rest of them made the target of solving their problems in speaking and being fluent in future practice in the class.

Based on the data obtained, the writer finds out that most of the participants were recorded to use the internet learning platforms such as Social media, online videos (youtube), and messengers (Whatsapp and Facebook). They admitted that having groups of learning in the social media enable them to learn from peers (overseas friend) and overcome their affective issues such as nervousness and anxiety compared to learning in the class with teachers. They were able to gain cognitive knowledge from the internet which can 
be used for the future practice of speaking. This had been proven successful by scholars in their study. Intisar Magboul et al. (2015) researched the useful contribution of social media towards the development of foreign language learning resulted in over $60 \%$ of the surveyed students (120 participants) improved their learning through the use of social media. Other research done by Xu (2012) found the similar result on how effective the internet environment affected the learning performance as the abundant of contents provided easy access to the students on picking the right material based on their needs, interest, and study level.

Another strategy in preparing their learning is by participating in a wide range of learning communities such as the English-speaking community, English debating community, and even tourist guides community. These communities, according to the participants, allowed them to practice their speaking as well as gaining knowledge on the component which forms a good speaking such as grammar, vocabulary, language chunks, and pronunciation from their peers in the community. This also solved their speaking issues such as self-doubt, uneasiness, and anxiety, as they were ready to practice their speaking in the future class. To support it, a study was done by Pujianto and Rakhmawati (2016) on the improvement of speaking using community-based learning revealed that grammar, vocabulary, and pronunciation can be improved through this activity. Morover, Chamot and Robbins (1995) stated that learners can develop their learning through competing for the tasks, receiving feedback, and build confidence when they apply cooperative learning in metacognitive strategy.

\section{Monitoring}

Learning refers to identify the issues during speaking practices. As the participants were fully aware of their weaknesses, they admitted to apply self-checking on their speaking performance. They revealed that they used socio-affective strategy and cognitive strategies to accommodate them in monitoring their speaking.

The socio-affective strategy is used by some of the participants by interacting with friends and lecturer to get feedback on their speaking performance. This strategy is also suggested by Chamot \& Kupper (1989) which they called Questioning and Cooperation. Furthermore, Cognitive strategies were also admitted to be applied during their process of monitoring their speaking activity. The self-correction strategy accommodates them to clarify their mistakes by spontaneously fixing their mistakes during speaking. This strategy is also suggested by Stewner-Manzanares et al. (1985) as self-correction is a crucial part of selfmonitoring. Other strategies which were used during their act of speaking is the time-gaining strategy, compensatory strategy, non-linguistic strategy, and code-mixing to maintain their speaking fluency.

\section{Evaluating}

In evaluating the speaking progress, the learners checked their learning outcome such as language repertoire, accuracy, and the cognitive strategy use after completing the tasks (Stewner-Manzanares et al., 1985). In line with the notion, the researcher found out that most of the participant used the cognitive strategies in the form of note-taking and voice recording to help the evaluation and listing their weakness for the future goal of learning. Another strategy which was also used by the participants in this phase was the socio-affective strategy. This strategy was applied by having their foreigner friends in social media to give feedback for their speaking after they have a speaking session online. The data obtained then used for the next cycle of metacognitive strategy.

\section{CONCLUSIONS AND SUGGESTIONS}

The application of metacognitive strategy in developing speaking skill done by high-achiever students was affected by their English language exposure during their school time before they attended the university. The lack of exposures of the English language before they attended university has encouraged them to make the best use of access to English resources and the English environment to develop their awareness using their cognitive knowledge. Furthermore, the various strategies used to accommodate the metacognitive strategy steps played a crucial role in forming the effectiveness of their speaking practices. Moreover, based on the findings, it is revealed that the use of an internet platform also took part in learning success. However, these facts need to be studied comprehensively for future studies, and how far it affected the language learners learning strategy.

\section{REFERENCES}

Celce-Murcia, M. (2008). Rethinking the role of communicative competence in language teaching. In Intercultural language use and language learning (pp. 41-57). Springer Netherlands.

Celce-Murcia, M., Dörnyei, Z., \& Thurrell, S. (1995). Communicative competence: A pedagogically motivated model with content specifications. Issues in Applied linguistics, 6(2), 5-35.

Chamot, A. U., \& Kupper, L. (1989). Learning strategies in foreign language instruction. Foreign language annals, 22(1), 13-22.

Chamot, A. U., \& Robbins, J. (2005, April). The CALLA Model: Strategies for ELL student success. In Workshop for Region (Vol. 10). 
Clarke, V., \& Braun, V. (2014). Thematic analysis. In Encyclopedia of critical psychology (pp. 1947-1952). Springer New York.

Creswell, J. W. (2013). Qualitative Inquiry and Research design, Choosing Among Five Approaches. 3rd Edition. Sage publications.

Creswell, J. W. (2013). Research design: Qualitative, quantitative, and mixed methods approaches. Sage publications.

Dörnyei, Z., \& Thurrell, S. (1991). Strategic competence and how to teach it

Hamilton, L., \& Corbett-Whittier, C. (2012). Using case study in education research. Sage.

Hymes, D.H. (1972) On Communicative Competence In: J.B. Pride and J. Holmes (eds) Sociolinguistics. Selected Readings. Harmondsworth: Penguin, pp. 269-293

Intisar Magboul, E., \& Anandhavalli, M. (2015). An effective contribution of social media networks in foreign language learning case study: Community diploma college, King Khalid University, KSA. International Journal of Emerging Technology and Advanced Engineering, 5(1), 438-442.f

O'malley, J. M., \& Chamot, A. U. (1990). Learning strategies in second language acquisition. Cambridge university press.

Oxford, R. L. (Ed.). (2003). Language learning styles and strategies. Mouton de Gruyter.

Paris, S. G., \& Winograd, P. (1990). Promoting metacognition and motivation of exceptional children. Remedial and special Education, 11(6), 7-15.

Raoofi, S., Chan, S. H., Mukundan, J., \& Rashid, S. M. (2013). Metacognition and second/foreign language learning. English Language Teaching, 7(1), 36

Rivers, W. P. (2001). Autonomy at All Costs: An Ethnography of Metacognitive SelfAssessment and SelfManagement among Experienced Language Learners. The modern language journal, 85(2), 279290.

Stewner-Manzanares, G. (1985). Learning Strategies in English as a Second Language Instruction: A Teacher's Guide.

Torky, S. A. E. (2006). The Effectiveness of a Task-Based Instruction Program in Developing the English Language Speaking Skills of Secondary Stage Students. Online Submission.

van Velzen, J. (2016). Metacognitive Knowledge in Theory. In Metacognitive Learning (pp. 13-25). Springer International Publishing.

Wei, C. (2008). Developing Laerners' Autonomy through Metacognitive Awareness Training in ELT. CELEA Journal (Bimonthly), 31(4), 110-120.

Xu, W. (2012). A Survey on Metacognitive Strategy Use in College Oral English Study under Internet Environment-With a Case Study of Guilin University of Technology. Theory and Practice in Language Studies, 2(7), 1430. 